2019

\title{
Phase 2 of the UNCITRAL ISDS Review: Why 'Other Matters' Really Matter
}

Gus Van Harten

Osgoode Hall Law School of York University, gvanharten@osgoode.yorku.ca

Jane Kelsey

Faculty of Law, University of Auckland

David Schneiderman

Faculty of Law, University of Toronto

Follow this and additional works at: https://digitalcommons.osgoode.yorku.ca/all_papers

Part of the Law Commons

\section{Repository Citation}

Van Harten, Gus; Kelsey, Jane; and Schneiderman, David, "Phase 2 of the UNCITRAL ISDS Review: Why 'Other Matters' Really Matter" (2019). All Papers. 328.

https://digitalcommons.osgoode.yorku.ca/all_papers/328 


\section{PHASE 2 OF THE UNCITRAL ISDS REVIEW: WHY 'OTHER MATTERS' REALLY MATTER ${ }^{1}$}

The United Nations Commission on International Trade Law (UNCITRAL) conferred a broad mandate on Working Group III (WGIII) to work on possible reform of Investor-State Dispute Settlement (ISDS) through a consensus-based, government-led process. ${ }^{2}$ The Working Group has completed Phase 1 , in which governments identified and considered concerns regarding ISDS. Phase 2 , where they consider whether reform is desirable in light of those concerns, is well advanced. The next meeting in New York in April 2019 is expected to conclude this phase, and decide how to pursue the final phase in which governments will develop any relevant solutions to recommend to the Commission.

The UNCITRAL process has acknowledged from the start that the essence of current criticisms of the investment law regime 'reflect[s] concerns about the democratic accountability and legitimacy of the regime as a whole. ${ }^{3}$ Investor-State arbitration, in particular, is criticised for, inter alia, displacing domestic adjudicatory decisions and domestic law and institutions, operating against the interests of developing States, creating conditions for regulatory chill, establishing a fundamental asymmetry in legal protection, creating an exclusive category of international dispute settlement for foreign investors, permitting monetary awards of very large size to investors who are affected negatively by sovereign conduct, omitting institutional protections against conflicts of interest, and creating other forms of unfairness in the arbitration process. There are also fundamental questions about whether the costs of investment treaties, particularly as a result of ISDS, outweigh their benefits in light of increasing doubts regarding the efficacy and efficiency of the treaties as tools for attracting sustainable investment, depoliticizing disputes, and improving the rule of law. ${ }^{4}$ These cumulative

\footnotetext{
${ }^{1}$ This paper is a contribution to the $37^{\text {th }}$ Session of UNCITRAL Working Group III, New York, April 2019, by Professor Jane Kelsey, Faculty of Law, University of Auckland, New Zealand; Professor David Schneiderman, Faculty of Law, University of Toronto, Canada; and Professor Gus Van Harten, Osgoode Hall Law School of York University, Toronto, Canada. The authors share common concerns about international investment agreements and ISDS, although we differ over the manner and extent to which we think these concerns can be resolved by the current UNCITRAL reform of the investment arbitration regime. We are grateful for comments on the paper from Lise Johnson, Columbia Center on Sustainable Investment, Columbia University, USA, and Lisa Sachs, Director of the Columbia Center on Sustainable Investment, Columbia University, USA. Responsibility for the views expressed are our own.

2 Report of the United Nations Commission on International Trade Law (UNCITRAL) (50 th Session) (3-21 July 2017) UN GAOR $71^{\text {st }}$ Session Supp No 17 UN Doc A/71/17 (2017) ( 'UNCITRAL Commission Report, 50 th Session'), para. 264. The mandate reads: 'The Commission entrusted Working Group III with a broad mandate to work on the possible reform of investor-State dispute settlement. In line with the UNCITRAL process, Working Group III would, in discharging that mandate, ensure that the deliberations, while benefiting from the widest possible breadth of available expertise from all stakeholders, would be Government-led, with high-level input from all Governments, consensus-based and fully transparent. The Working Group would proceed to: (a) first, identify and consider concerns regarding investor-State dispute settlement; (b) second, consider whether reform was desirable in the light of any identified concerns; and (c) third, if the Working Group were to conclude that reform was desirable, develop any relevant solutions to be recommended to the Commission. The Commission agreed that broad discretion should be left to the Working Group in discharging its mandate, and that any solutions devised would be designed taking into account the ongoing work of relevant international organizations and with a view to allowing each State the choice of whether and to what extent it wished to adopt the relevant solution(s).'

3 UNCITRAL 'Possible future work in the field of dispute settlement: Reforms of investor-State dispute settlement (ISDS): Note by the Secretariat' (20 April 2017) A/CN.9/917 (UNCITRAL Secretariat Note, A/CN.9/917), para. 12. See also UNCITRAL Working Group III 'Possible reform of investor-State dispute settlement (ISDS): Note by the Secretariat' (18 September 2017) A/CN.9/WG.III/WP.142 (Note by the Secretariat, WP.142), paras. 45-47.

4 UNCITRAL 'Report of the Working Group III (Investor-State Dispute Settlement Reform) on the work of its 35th session (New York, 23-27 April 2018)' (14 May 2018) A/CN.9/935 (UNCITRAL Working Group III Report, 35th Session), paras. 94 and 97. L. Johnson et al., 'Costs and Benefits of Investment Treaties: Practical Considerations for States' (CCSI 2018); J. Pohl, 'Societal Benefits and Costs of International Investment Agreements' (2018) OECD Working Papers on International Investment No. 2018/1.
} 
concerns have informed calls for UNCITRAL 'to take a holistic view of the system, especially of whether it was achieving its purported objectives, when considering and designing any ISDS reform. ${ }^{5}$

Despite the breadth of the UNCITRAL mandate and the concerns expressed by Member States and others, the scope of this reform has so far been unduly narrow. There are two related causes for this: one is an interpretation that Working Group III's work is limited to issues of procedure and not substance; the other is the framing and organization of the discussions.

On the substance-process issue, some members of Working Group III have interpreted the mandate as 'focus[ing] on the procedural aspects of dispute settlement rather than on the substantive provisions. ${ }^{6}$ Yet the contributions of a number of participating governments suggest there is no consensus to that effect. ${ }^{7}$ Substantive rules of investor protection and investor-state arbitration are in key respects inseparable: procedural law is sometimes inherently substantive, investment arbitration is used to enforce states' substantive obligations, and critical questions of possible ISDS reforms involve the underlying rules. ${ }^{8}$ Another example is the use of ISDS in treaties to override the contractually-agreed exclusive forum for resolving a substantive dispute.

Given that the Commission's mandate to Working Group III was broad and not explicitly limited to procedural aspects of ISDS, ${ }^{9}$ the notion of what is 'procedural' should at least be interpreted expansively. To some extent Working Group III has already adopted this view by accepting that issues of substantive correctness and coherence in the law are matters it can try to address. ${ }^{10}$ That implies a belief that problems which may arise from opaque substantive investor protections in the treaties might be addressed in part by certain procedural tools.

The second reason why the scope of reform has been too narrow to date is the framing of the discussion. That framing will, in turn, unduly constrain reform efforts during Phase 3. Discussion has been directed to three categories of issues, ${ }^{11}$ each supported by a secretariat Working Paper: (1) concerns pertaining to consistency, coherence, predictability and correctness of arbitral decisions; ${ }^{12}$

\footnotetext{
${ }^{5}$ UNCITRAL Working Group III Report, 35th Session, para. 97.

${ }^{6}$ UNCITRAL, 'Report of the Working Group III (Investor-State Dispute Settlement Reform) on the work of its 34th session (Vienna, 30 November-1 December 2017)' (19 December 2017) A/CN.9/930/Rev.1 (UNCITRAL Working Group III Report, 34th Session), para. 20.

${ }^{7}$ See discussion in the $51^{\text {st }}$ session of the UNCITRAL Commission, notably the exchange between Thailand and Mauritius in the afternoon of 28 June 2018, which can be heard in the audio recordings of the UNCITRAL sessions (available at https://icms.unov.org/CarbonWeb/public/uncitral/speakerslog/273f4406-24be-49e5-90e6-d2ca1d85d2ac). See also UNCITRAL Commission Report, 50th Session, paras. 257-265; UNCITRAL Working Group III Report, 34th Session, para. 20.

${ }^{8}$ Indonesia has most recently expressed this view in a paper entitled 'ISDS Reform; A brief perspective from Indonesia', which was informally tabled at the $36^{\text {th }}$ session of Working Group III in Vienna in November 2018 and is slated for discussion at the $37^{\text {th }}$ session in New York in April 2019: UNCITRAL Working Group III (Investor-State Dispute Settlement Reform), $37^{\text {th }}$ Session, 1-5 April 2019, 'Possible reform of Investor-State dispute settlement. Comments by the Government of Indonesia' (9 November 2018) A/CN.9/WG.III/WP.156 (UNCITRAL WP.156).

${ }^{9}$ UNCITRAL Commission Report, 50 ${ }^{\text {th }}$ Session, paras. 263 and 264.

${ }^{10}$ See especially Note by the Secretariat, WP.142, para. 53.

11 UNCITRAL Secretariat Note, A/CN.9/917; UNCITRAL Working Group III (Investor-State Dispute Settlement Reform) 'Possible reform of investor-State dispute settlement (ISDS): Note by the Secretariat' (5 September 2018) A/CN.9/WG.III/WP.149 (UNCITRAL Secretariat Note, WP.149), paras. 8-16. This approach appears to have been influenced by a study commissioned by the Secretariat in conjunction with the Centre for International Dispute Settlement on whether the Mauritius Convention could provide a useful model for possible reform of investor-State arbitration: G. Kaufmann-Kohler and M. Potestà, 'Can the Mauritius Convention Serve as a Model for the Reform of Investor-State Arbitration in Connection with the Introduction of a Permanent Investment Tribunal or an Appeal Mechanism? - Analysis and Roadmap' (3 June 2016) $<w w w$.uncitral.org/pdf/english/commissionsessions/unc/ unc-49/CIDS_Research_Paper_-_Can_the_Mauritius_Convention_serve_as_a_model.pdf.

12 UNCITRAL Working Group III (Investor-State Dispute Settlement Reform) 'Possible reform of investor-State dispute settlement (ISDS): Consistency and related matters. Note by the Secretariat' (28 August 2018) A/CN.9/WG.III/WP.150.
} 
(2) concerns pertaining to arbitrators and decision-makers; ${ }^{13}$ and (3) concerns pertaining to cost and duration of ISDS cases $^{14}$. Participating governments have agreed that these issues merit multilateral reform.

Although these three issues are important, they are far from a diligent catalogue of identified problems with ISDS. Working Group III has not yet dedicated time to a broader set of fundamental issues at the heart of widespread discontent with the system. In proposing the three narrower topics for discussion, the Secretariat acknowledged that participating governments may raise other matters and 'the Working Group may wish to expand its consideration of other relevant issues'. ${ }^{15}$ Indeed, before and after those three topics were isolated for the agenda, a number of governments have raised concerns whose breadth and significance warrant a stand-alone discussion, also supported by substantive research. ${ }^{16}$ However, their issues have been aggregated under the general category of 'Other concerns', ${ }^{17}$ and not yet discussed. ${ }^{18}$ The Working Group III chair has stated there will be an opportunity for such discussion at the next session in New York in April 2019.

This note therefore raises two of the issues that are critical to the discussions of 'other concerns', and that require reform through Phase 3:

1. the right to participation by affected parties: ISDS excludes others from full standing in the process of deciding foreign investor claims. Therefore, (a) investors can make allegations against people and organizations that have no right to reply and (b) ISDS tribunal decisions can impact other parties' rights and interests without the tribunal having heard from them.

2. the rule of law and domestic courts' jurisdiction: ISDS permits foreign investors to circumvent a country's courts, regardless of whether they offer justice. This option allows foreign investors to avoid the ordinary laws and courts that govern everyone else.

\footnotetext{
13 UNCITRAL Working Group III (Investor-State Dispute Settlement Reform) 'Possible reform of investor-State dispute settlement (ISDS): Ensuring independence and impartiality on the part of arbitrators and decision makers in ISDS. Note by the Secretariat' (30 August 2018) A/CN.9/WG.III/WP.151; UNCITRAL Working Group III (Investor-State Dispute Settlement Reform) 'Possible reform of investor-State dispute settlement (ISDS): Arbitrators and decision makers: appointment mechanisms and related issues. Note by the Secretariat' (30 August 2018) A/CN.9/WG.III/WP.152.

14 UNCITRAL Working Group III (Investor-State Dispute Settlement Reform) 'Possible reform of investor-State dispute settlement (ISDS): Cost and duration. Note by the Secretariat' (31 August 2018) A/CN.9/WG.III/WP.153.

${ }^{15}$ Note by the Secretariat, WP.142, para. 19.

${ }^{16}$ In the 35th session, concerns were raised, for instance, regarding: the lack of obligations on foreign investors (see, e.g., interventions on Monday morning, April 23, 2018, starting at 1:14:40 and 2:01:38); regulatory chill and impacts on the right to regulate in the public interest and achieve sustainable development outcomes (e.g., interventions on Monday morning, April 23, 2018, starting at 1:14:40 and 2:01:38, and Tuesday morning, April 24, 2018, starting at 1:07:51 and 2:22:05, and Chair comments at 2:36:59); the relationship with domestic law and domestic courts (e.g., interventions on Monday morning, April 23, 2018, starting at 2:05:30, and Monday afternoon, April 23, 2018, starting at 2:54:45); the asymmetrical nature of the system (e.g., intervention on Monday morning, April 23, 2018, starting at 2:01:38); issues of arbitrability and overreaching by adjudicators (e.g., intervention on Thursday morning, April 26, 2018, at 2:37:00); and the role of the home state (e.g., intervention on Tuesday morning, April 24, 2018, starting at 2:16:23). All times referred to are the elapsed time in the English language recording (available at http://www.uncitral.org/uncitral/audio/meetings.jsp).

17 UNCITRAL Secretariat Note, WP.149, para. 17 ('4. Other concerns[:]At the thirty-fifth session of the Working Group, it was emphasized that States would have the opportunity to raise additional concerns at future sessions of the Working Group (A/CN.9/935, para. 99). The Working Group may wish to consider whether other concerns pertaining to the ISDS regime, not identified above and in documents A/CN.9/WG.III/WP.150 to A/CN.9/WG.III/WP.153 would need further consideration. ${ }^{\prime}{ }^{\prime}$ ). The text to note 6 in this excerpt reads: 'In this regard, the Working Group may wish also to take into consideration the issues raised in papers and statements submitted for its consideration at its thirty-fourth and thirty-fifth sessions (available at http://www.uncitral.org/uncitral/en/commission/working groups/3Investor State.html), and the materials available at the link entitled 'Investor-State Dispute Settlement Reform: On-line Resources.'

18 The agenda for the 36th session of Working Group III in Vienna in October 2018 was tightly framed around the issues of coherence, appointment of arbitrators, and cost and duration, as per UNCITRAL Secretariat Note, WP.149.
} 
We elaborate on these issues in the main body of this paper.

In addition, a fragmented approach to the three selected issues in Phase 2 has had the added consequence of excluding the consideration of cross-cutting and more systemic concerns. In particular, a number of delegates have expressed concern that cost, lack of coherence and consistency, and the nature and conduct of arbitrators, among other factors, have a chilling effect on their regulatory capacity and sovereignty. ${ }^{19}$ These concerns about the chilling effect of ISDS require specific, individualized attention during the remainder of Phase 2 to ensure that future work in Phase 3 considers the effectiveness of proposed solutions to address this widely-expressed concern.

Finally, it is axiomatic that the conclusions from Phase 2 and the solutions proposed in Phase 3 need to be assessed with reference to the objectives of the international investment regime itself and to reflect UNCITRAL's location within the United Nations. Pre-eminent among these considerations is the commitment of states to the UN Sustainable Development Goals. The final section of this paper therefore highlights the relationship of Working Group III deliberations in Phases 2 and 3 to the ultimate goal of, and commitment to, sustainable development. Participants are also urged to integrate mechanisms for assessing the achievement of these objectives into any work plan for Phase 3.

\section{Right to participation by affected parties}

ISDS excludes others from the process of deciding foreign investor claims. Therefore, (a) investors can make allegations against people and organizations that have no right to reply and (b) ISDS tribunal decisions can impact other parties' rights and interests without the tribunal having heard from them.

A striking procedural flaw in ISDS is the exclusion of non-investors from the adjudication of claims. In a legal proceeding, any person who has an affected interest should normally have a right to standing in the process, at least to the extent of the affected interest. ${ }^{20}$ Yet, when foreign investors sue countries, they often make allegations and raise issues that affect others who have no legal right to participate. In a fair process, all affected parties would have notice of the claim and its relevance to their interests and an opportunity to decide whether to seek standing. Where an affected party is denied the right to standing, the adjudicator cannot hear all sides of the dispute and is presumptively unable to consider relevant facts and arguments, and may issue decisions and relief prejudicial to those not present.

ISDS is unfair, therefore, because it does not give a right of standing to all parties affected by the adjudication of foreign investor claims. Instead, it gives a right of standing to the foreign investor that brings the claim and to the respondent country, usually represented by its national government. No one else whose rights or interests, including reputational interests, are affected by the claim can have standing as a party, regardless of the extent to which these rights or interests are affected.

\footnotetext{
${ }^{19}$ See, e.g., UNCITRAL Working Group III Report, 35th Session, para. 97; UNCITRAL 'Report of the Working Group III (InvestorState Dispute Settlement Reform) on the work of its 36th session (Vienna, 29 October-2 November 2018)' (6 November 2018) A/CN.9/964 (UNCITRAL Working Group III Report, 36 th Session), para. 111. See also, interventions on Monday morning, April 23, 2018, starting at 1:14:40 and 2:01:38; and interventions Tuesday morning, April 24, 2018, starting at 1:07:51 and 2:22:05, and Chair comments at 2:36:59. All times referred to are the elapsed time in the English language recording.

${ }^{20}$ e.g. G. Heckman, D. Mullan, J. Promislow, and G. Van Harten, Administrative Law - Cases, Text, and Materials $\left(7^{\text {th }}\right.$ edn, Emond Publishing 2015), ch. 3.
} 
Various actors may be left in this unfair situation, such as an individual accused of involvement in corruption, ${ }^{21}$ a domestic investor in competition with foreign competitors, ${ }^{22}$ a sub-national government alleged to have violated the treaty, ${ }^{23}$ communities whose land claims overlap with those of the foreign investor, ${ }^{24}$ or private parties engaged in domestic litigation with the foreign investor. ${ }^{25}$ Under the current ISDS system, none of these parties has a right to standing in the adjudication. To reply effectively on issues relating to one's rights or interests, the affected party should have access to the relevant evidence put before the tribunal, an opportunity to test the evidence, an opportunity to make claims and submit evidence, and so on. As the proceedings unfold, it may emerge that the party can provide facts that the investor and government could not or did not provide. Where the person has been denied the right of standing, an ISDS tribunal risks making a decision that harms someone without having heard from him or her. That is deeply unfair.

In its past proposals for ISDS in trade agreements, the European Union took a partial step to address this aspect of ISDS. The proposal included a right of intervention for anyone with a direct interest in the proceeding, albeit limited to the option of supporting the claimant investor's or the respondent state's position. ${ }^{26}$ This proposal went some way to addressing the lack of procedural fairness in ISDS, but it did not find its way into the text of the EU-Singapore FTA, the EU-Vietnam FTA or the EU-Canada CETA. ${ }^{27}$

A weaker approach to this procedural issue, included in North American treaty provisions on ISDS since the early 2000s and a number of more recent agreements and procedural rules, has been to allow ISDS arbitrators to give amicus or limited 'third person' status. ${ }^{28}$ However, this step falls well short of fairness because amicus representation does not require tribunals to give standing to persons who have a direct interest in the proceeding. ${ }^{29}$ Moreover, in rare cases where tribunals have granted amicus status, the rights of participation have been severely limited. ${ }^{30}$ The amicus party is not entitled

\footnotetext{
${ }^{21}$ Saint Marys v Canada, Claimant's Notice of Intent to Submit a Claim to Arbitration, Ad hoc-UNCITRAL Arbitration Rules, 12 May 2011, paras. 1 and 33-4.

22 Eureko v Poland, Dissenting Opinion of Rajski, Ad hoc, 19 August 2005, para. 11.

${ }^{23}$ AbitibiBowater v Canada, Claimant's Notice of Intent to Submit a Claim to Arbitration, ICSID Case No. UNCT/10/1, 23 April 2009, paras. 8-9.

${ }^{24}$ Pezold v Zimbabwe, Procedural Order No. 2, ICSID Case No. ARB/10/25, 26 June 2012, para. 62.

25 See, e.g., Chevron v. Ecuador, where the tribunal rejected Ecuador's cross-claims on the ground that the government did not have standing to assert the claims, which dealt with environmental harm that affected Ecuadorian citizens individually (Second Partial Award on Track II, 30 August 2018, PCA Case No. 2009-23, paras. 7.39-7.44). Yet a key issue was whether Chevron could use ISDS to attack a domestic court ruling against Chevron and in favour of private plaintiffs who had suffered from the environmental harm. See, e.g., Chevron v. Ecuador, Second Partial Award on Track II, 30 August 2018, PCA Case No. 2009-23, paras. 9.20-9.97, Part X. See also Chevron v. Ecuador, Interim Award, 15 January 2012, 11 \& 16; Chevron v. Ecuador, Second Interim Award, 16 February 2012, para. 3; Chevron v. Ecuador, Third Interim Award on Jurisdiction and Admissibility, 27 February 2012, paras. 4.59-4.71. See also L. Johnson and B. Skartvedt Güven, 'The Settlement of Investment Disputes: A discussion of democratic accountability and the public interest', Investment Treaty News (13 March 2017).

26 Proposed TTIP investment chapter, art. 23 ('The Tribunal shall permit any natural or legal person which can establish a direct and present interest in the result of the dispute (the intervener) to intervene as a third party...').

${ }^{27}$ Canada-EU Comprehensive Economic and Trade Agreement (29 February 2016) [CETA], art. X.3; EU-Singapore Free Trade Agreement (29 June 2015) [Singapore FTA], art. 9.14(2)(a) (definition of 'disputing parties'); EU-Vietnam Free Trade Agreement (2 December 2015) [Vietnam FTA], art. 2 of ch. II, sec. 3 (definition of 'disputing parties'). None of the agreements incorporate the draft art. 23 provision, ibid.

28 e.g. Singapore FTA, art. 3 of annex 9-G; Comprehensive and Progressive Agreement for Trans-Pacific Partnership (released 21 February 2018), art. 9.23(3).

29 P. Wieland, 'Why the Amicus Curia Institution is III-suited to address Indigenous Peoples' Rights before Investor-State Arbitration Tribunals: Glamis Gold and the Right of Intervention' (2011) 3 Trade, Law and Development 334, 344-5 and 35960; see also N. Blackaby and C. Richard, 'Amicus Curiae: A Panacea for Legitimacy in Investment Arbitration?' in M. Waibel et al (eds.), The Backlash Against Investment Arbitration (Kluwer Law International 2010) 253, 259-266.

$30 \mathrm{lbid}$ (Wieland at 341-4).
} 
to full access to all relevant documents before the tribunal ${ }^{31}$ and therefore may need to draft its submission without knowledge of what the investor and government have told the tribunal. This raises particular challenges for would-be amici who are instructed by tribunals that their submissions must be within the scope of the existing dispute, ${ }^{32}$ make contributions distinct from the other parties, ${ }^{33}$ and not favour one 'side' or the other. ${ }^{34}$ Additionally, tribunals have directed amici to limit their input to narrow issues of fact or law. ${ }^{35}$ Above all, tribunals are not obliged to grant standing to any affected party that seeks it, to the full extent of the party's interest. ${ }^{36}$

To be clear, it is not the idea of amicus that is the problem; it is the misuse of that idea in ISDS. In other areas of law, amicus is used to give individuals and groups an opportunity to participate in a proceeding where they otherwise have no right of full standing. That procedural option can be very helpful but its purpose is very different from that of ensuring that affected parties are heard and able to protect their rights and interests. Amicus was never meant as a substitute for the right of standing. For ISDS to be fair in this regard, it would have to safeguard the rights of all affected parties, including by giving them a right of standing to the extent of their affected interest.

\section{The example of Pezold $v$ Zimbabwe}

In the ISDS case of Pezold $v$ Zimbabwe, the claimants sought a ruling in a dispute about land. ${ }^{37}$ Four indigenous communities (and an organization called the European Center for Constitutional and Human Rights) had available to them only the limited option of applying to the tribunal for amicus status to participate in the process. If granted amicus status, the parties would have been able to make limited submissions to the extent that the tribunal allowed. The tribunal denied them even this limited opportunity to participate, justifying this decision on the basis that giving status to the communities could undermine the foreign investor's ability to make its own claims about the land (in the absence of the other affected parties!).

According to the tribunal's order on amicus, the communities had told the tribunal that 'they each have a distinct cultural identity and social history which is inextricably linked to their ancestral lands', which were in turn affected by the investor's claim. ${ }^{38}$ The communities also said that the ISDS arbitration went beyond the interests of the investor and government alone because it 'may also potentially impact on the indigenous communities' collective and individual rights' ${ }^{39}$ The investor argued against giving the communities an opportunity to be heard but acknowledged, as the tribunal put it, that the communities 'have some interest in

\footnotetext{
${ }^{31}$ Infinito Gold v. Costa Rica, Procedural Order No. 2, ICSID Case No. ARB/14/5, 1 June 2016, paras. 43-45

32 ICSID, Rule 37(2)(b).

33 ICSID, Rule 37(2)(a); see also Gabriel Resources Ltd. v. Romania, Procedural Order No. 19, ICSID Case No. ARB/15/31, 7 December 2018, paras. 50 and 62.

${ }^{34}$ Infinito Gold v. Costa Rica, Procedural Order No. 2, ICSID Case No. ARB/14/5, 1 June 2016, para. 38.

${ }_{35}$ Gabriel Resources Ltd. v. Romania, Procedural Order No. 19, ICSID Case No. ARB/15/31, 7 December 2018, paras. 60 and 66 (preventing the submission from dealing with legal matters and limiting the factual submissions to issues that 'do not refer to or rely on testimonies').

${ }^{36}$ E. Levine, 'Amicus Curiae in International Investment Arbitration: The Implications of an Increase in Third-Party Participation' (2012) 29 Berkeley Journal of International Law 200, 208-14; A. Salazar, 'Defragmenting International Investment Law to Protect Citizen-Consumers: The Role of Amici Curiae and Public Interest Groups' (2013) Osgoode Hall Law School, Comparative Research in Law \& Political Economy Research Paper No 6/2013, 4-8.

${ }^{37}$ Pezold v. Zimbabwe, Procedural Order No. 2, ICSID Case No. ARB/10/25, 26 June 2012.

$38 \mathrm{lbid}$, para. 21.

$39 \mathrm{lbid}$, para. 21.
} 
the land over which the Claimants assert full legal title'.$^{40}$ For its part, the tribunal admitted that '[i]t may therefore well be that the determination of the Arbitral Tribunals in these proceedings will have an impact on the interests of the indigenous communities'. ${ }^{41}$ Even so, the arbitrators denied the communities any opportunity to participate, as amicus or otherwise, due to their 'reservations as to the independence and/or neutrality' of the communities. ${ }^{42}$ The tribunal pointed to a requirement in the relevant arbitration rules that the communities needed not only to have an interest in the proceeding but also to be 'independent' of the other parties. ${ }^{43}$ Because the communities and their structure of government had some links to the Zimbabwean state, the tribunal decided that giving them even the limited amicus role would 'unfairly prejudice' the investor. ${ }^{44}$

By this approach, the Pezold tribunal turned fairness upside down: a gross unfairness to a group of affected parties was said to be required to ensure 'fairness' to the only private party with standing in the proceeding. Such is the level of privilege for foreign investors in ISDS. It should have been beside the point, for the tribunal, whether or not the communities agreed with the government because part of the right of standing is the ability to choose one's legal position and not have it pre-judged by the adjudicator. If a party thinks that its interests are best served by supporting the position of another party, it should in general be able to take that approach, and it was especially presumptuous for the tribunal to suppose how the communities would represent themselves before the communities could even review the full file based on a right of standing. Despite these particularly egregious features of the Pezold decision, even if the tribunal had granted amicus status to the other affected parties, the process and outcomes would still have been unfair, to the extent that they affected rights or interests of those parties, because the affected communities would have been denied their basic right of standing.

\section{The rule of law and domestic courts' jurisdiction}

ISDS procedures permit foreign investors to circumvent a country's courts, regardless of whether they offer justice. This option allows foreign investors to avoid the ordinary laws and courts that govern everyone else.

In customary international law, there has long been a rule that private parties must exhaust local remedies before their grievances can lead to an international claim against a country. ${ }^{45}$ In rare cases where treaties - other than ISDS treaties - allow private claims against countries, the right comes with this usual duty to exhaust local remedies. The duty exists for good reasons. It shows respect for the country's institutions and gives the country a chance to fix problems before they are brought to an international tribunal. It sets up international tribunals as a supplement, instead of a substitute, for domestic courts. It allows the courts to hear the grievance and rule on the relevant facts and law; this

\footnotetext{
$40 \mathrm{lbid}$, para. 62.

${ }^{41} \mathrm{lbid}$, para. 62.

$42 \mathrm{Ibid}$, para. 62.

43 Ibid, para. 62, citing ICSID Rule 37(2) criteria.

$44 \mathrm{lbid}$, para. 62.

45 e.g. S. D'Ascoli and K.M. Scherr, 'The Rule of Prior Exhaustion of Local Remedies in the International Law Doctrine and its Application in the Specific Context of Human Rights Protection' (2007) European University Institute (EUI) Working Paper LAW No. 2007/02.
} 
record is then available to help an international tribunal, if relevant, conduct its own review. For foreign nationals, the duty reflects the idea that their choice to enter a country carries a responsibility to accept domestic laws and institutions. Thus, it conveys that no one is above the law. Moreover, the duty always accounted for situations in which a country's legal system or courts were unreliable. It allowed an international tribunal to waive the duty if a foreign national showed that local remedies were not reasonably available or would be obviously futile to pursue.

In ISDS, foreign investors have been excused from this duty completely. ${ }^{46}$ This step has opened up all sorts of lawyering options for investors, who have the sole discretion to decide on the reliability and suitability of local remedies. It enables ISDS lawyers to intensify pressure on governments as a tool for regulatory chill and enhance the prospect of public compensation for investors. Some investors have gone to domestic courts first and then brought an ISDS claim if they did not win. Other investors, in contrast, have side-stepped the courts by challenging a country's decisions without going to the courts first; or, investors have gone to both forums in parallel. ${ }^{47}$ These alternative strategies can allow investors to seek an international order of compensation against the country, thus avoiding limits on judicial awards of compensation in domestic law, while also pursuing other remedies - such as the striking down of a law - in domestic courts. ${ }^{48}$ Investors can also invoke ISDS for low-level problems that could have been addressed in the courts. Relieved of the usual duty to exhaust local remedies, foreign investors gain a unique freedom to mold and limit their relationship with a country's institutions.

For example, courts in many countries tend to show restraint when they review decisions by elected legislatures and expert regulators. ${ }^{49}$ They show this deference out of respect for the relative accountability or capacity of another institutional decision-maker. In international law, doctrines of deference are less developed. Indeed, beyond investment treaties, international law has little experience in the direct review of domestic legislatures or regulators - in response to individual claims - since the duty to exhaust local remedies has long acted as a buffer between international review and domestic institutions. By removing the customary duty, investment treaties empower investors to avoid domestic principles of deference by going straight to ISDS, where tribunals have not adopted similar principles to limit their own role, despite submissions by governments that they should. ${ }^{50}$ Thus, ISDS has been used to enhance access to public compensation, especially by those most able to finance ISDS litigation - i.e. large multinationals and the ultra-wealthy - at the expense of democratic choice and regulatory flexibility. The rise of third-party funding intensifies this effect.

Moreover, ISDS arbitrators have regularly allowed foreign investors to avoid contractual commitments where investors previously agreed to use domestic courts or another forum to resolve their disputes with the state. Contracts between foreign companies and governments typically have dispute settlement clauses that require all parties to use a specific forum for resolving disputes under

\footnotetext{
46 Or, the duty is removed with limited conditions such as a 6-month wait period, which have themselves usually been discounted by ISDS tribunals via creative reasoning. G. Van Harten, Sovereign Choices and Sovereign Constraints: Judicial Restraint in Investment Treaty Arbitration (Oxford University Press 2013) 147-150.

47 e.g. GAMI Investments, Inc $v$ Government of the United Mexican States, Award, Ad hoc-UNCITRAL Arbitration Rules, 44 ILM 545, 15 November 2004.

48 e.g. CETA tracks the old NAFTA approach, which merely requires foreign investors to pursue monetary remedies either in ISDS or domestic courts but not both. This approach allows to pursue public compensation in ISDS where compensation is (remarkably) the primary remedy, while also pursuing non-monetary remedies in domestic courts where compensation is typically not the primary remedy. See Van Harten (n 46 above) 113-114.

${ }^{49}$ Van Harten (n 46 above) ch. 2.

$50 \mathrm{lbid}$ at 59-61.
} 
the contract. Courts usually enforce these provisions by requiring a party to go to the agreed forum before bringing an action in court. This approach is consistent with the principles that a contract reflects the will of the parties and that it should be enforced. For their part, ISDS arbitrators have often pointed to principles of party autonomy and contractual sanctity to justify treaty interpretations that favour the expansion of the arbitrators' own power. Yet when the principles call for respect for a contractually-agreed forum, ISDS arbitrators have regularly allowed investor claims to go ahead under the treaty. ${ }^{51}$

This claimant-friendly approach amounts to a de facto policy to favour parallel claims..$^{52}$ Its impact on public budgets has been immense. Roughly half of ISDS cases appear to relate to a contract that likely has its own dispute settlement clause..$^{53}$ Most of the cases in question would not exist, at least in the first instance, if the tribunal required the investor to use the contractually-agreed forum. As a consequence, foreign investors are able to negotiate contracts with states without having to worry, as much as other actors, about dispute settlement clauses; they have the exclusive option of ISDS to protect them. In this way, arbitrators have applied the treaties in a manner that distorts market relations at the expense of principles of party autonomy and sanctity of contract.

It is certainly true that some countries have weak or corrupt courts, leading ISDS promoters to often ask, how can one expect foreign investors to use domestic courts? Their answer is to have more investment treaties and ISDS. It is a simple answer, and problematic for four reasons.

First, the treaties are too sweeping. They remove the duty for all countries, not just the ones with weak courts.

Second, as mentioned, the customary duty always accounted for weak courts. It allows a foreign national to avoid local remedies by showing that such remedies are not reasonably available. It should not be onerous to show that weak or corrupt courts fail this test. Any investor who does so would then be relieved of the duty to use them.

Third, if foreign investors do not want to depend on a country's courts, they can avoid investing in the country or they can seek to protect themselves in contracts with the state by referring disputes to some other forum. The treaties interfere with these market options for all investors to decide the level of risk they wish to accept.

Fourth, the treaties do not replace weak courts with strong ones. Instead, they replace them with arbitrators who are not independent and impartial, fair, and open in the manner of any court worthy of the name. Indeed, the logic of ISDS promoters leads to the dismissal of any role for domestic courts at the sole discretion of foreign investors. By removing the duty completely, the treaties presume implicitly that courts everywhere are so inadequate that foreign investors should always be able to opt out of them, without even having to explain why. The weaknesses of some courts are not a justification for dismissing all courts.

As governments have sought to expand treaties that provide for ISDS to countries that have wellestablished and reliable courts, a new or perhaps the real purpose of ISDS-based protection became clear: to allow foreign investors, where it suits them, to replace courts with tribunals that are financially dependent on investors in ways that an independent court would not be, and to move their

\footnotetext{
$51 \mathrm{lbid}$ at $143-147$.

$52 \mathrm{Ibid}$ at 146-147.

53 Ibid at $155-156$.
} 
disputes to fora where the substantive law, procedural rules, remedies and/or adjudicators are more and often unfairly favorable to their claims. In some countries, foreign investors thus gain the option of exploiting weak domestic institutions to avoid accountability but also, if those institutions do not meet their expectations, to sue the country internationally. The end result is the best of both worlds for foreign investors: accountability for others and a way to avoid accountability for themselves.

\section{Chilling Sovereign States' Authority and Their Responsibility to Govern}

The chilling effect of substantive investor protections and ISDS procedures on states' policy, regulatory, and judicial processes is skewing decisions in favour of corporate interests and eroding the ability and responsibility of sovereign governments to protect and advance the public interest.

Concerns about the chilling effect of the international investment regime on the ability of sovereign states to exercise their authority lie at the core of the crisis of legitimacy that was the catalyst for the current UNCITRAL review. Pro-investor rules, enforced through the ISDS mechanism, are seen to undermine state sovereignty and states' constitutional obligations, subordinate the state's responsibility to regulate in the public interest and the public good, and erode democratic electoral mandates, processes, and accountability.

Specific concerns go well beyond the fiscal cost of defending disputes and payment of exorbitant awards. When measures designed to advance the public good are stopped, delayed, or weakened, there are always opportunity costs, as well as downstream financial costs, such as for health expenditure or environmental remediation. There may also be non-monetary ecological and human costs, as with delayed action on climate change. Governments face their own legitimacy crises when they are unable to respond to the social, economic, or cultural needs of their citizens, which may carry severe political consequences. Likewise, adjudicatory chill may undermine the rule of law by denying effective access to justice and remedies for vulnerable or exploited communities. The development asymmetries between capital importing and exporting countries mean the impact of chill cuts most deeply for poorer countries, and for the ability of governments to deliver to the world's most vulnerable communities.

Several participating governments have explicitly mentioned the chilling effect of ISDS as a concern they want the UNCITRAL reform to address. ${ }^{54}$ Chill can be seen as both a systemic problem of the international investment regime, and as a cross-cutting issue arising from the three specific concerns discussed in Phase 2 so far and from other concerns that are likely to be raised for discussion in the Paragraph 17 deliberations. If the procedural contributors to regulatory chill are not identified during Phase 2, it will be impossible to ensure they are effectively addressed during any consideration of proposed solutions in Phase 3. However, the fragmented structure of the Phase 2 agenda has so far precluded a dedicated discussion of these concerns.

While conclusive empirical evidence of the chilling effect is notoriously difficult to establish, the following analysis draws on a rapidly expanding literature in academic scholarship, ${ }^{55}$ international

\footnotetext{
${ }^{54}$ For example, UNCITRAL Working Group III Report, 36th Session, para. 111; and UNCITRAL Note by Secretariat, WP.156, para. 10. See also interventions on Monday morning, 23 April 2018, starting at 1:14:40 and 2:01:38; and interventions Tuesday morning, 24 April 2018, starting at 1:07:51 and 2:22:05, and Chair comments at 2:36:59. All times referred to are the elapsed time in the English language recording.

55 G. Van Harten, Investment Treaty Arbitration and Public Law (Oxford University Press 2007); D. Schneiderman, Constitutionalizing Economic Globalization (Cambridge University Press 2008); K. Tienhaara, 'Regulatory Chill and the Threat
} 
institutions, ${ }^{56}$ trade diplomats, ${ }^{57}$ government reports, ${ }^{58}$ and NGO studies. ${ }^{59}$ It is also significant that the phenomenon has been recognised by arbitrators themselves. ${ }^{60}$

While some interpret the scope of chill very narrowly, ${ }^{61}$ the above literature recognises that chill can take many different forms:

(i) Direct or specific deterrence arising from a threatened or actual investment dispute that results in a government decision not to proceed with a measure or lengthy delay to the introduction of the measure. Alternatively, the government might seek to mitigate the impact on a foreign investor by changing the measure in ways that reduce its efficacy or by adopting an alternative measure to that which it considers optimal to achieve the desired public benefit.

(ii) Indirect deterrence, whereby one or more other countries decide not to adopt, or to delay the introduction of, a specific measure because it is subject to an investment dispute elsewhere.

(iii) Systemic chill occurs where an assessment of the risk of an investment dispute is integrated into government policy-making and regulatory processes. The impact of these assessments has increased with the rapid growth in the number, scope, and monetary value of ISDS disputes and the pursuit of legal challenges through multiple domestic and international forums, increasingly supported by third-party funding. Systemic chill operates in multiple ways:

of Arbitration: A View from Political Science' in C. Brown \& K. Miles (eds), Evolution in Investment Treaty Law and Arbitration (Cambridge University Press 2011) 606-628; J. Bonnitcha, Substantive Protection Under Investment Treaties. A Legal and Economic Analysis (Cambridge University Press 2014); K. Cooper, K. Bell-Pasht and R. Nadarajah, 'Seeking a Regulatory Chill in Canada. The Dow Agrosciences NAFTA Chapter 11 Challenge to the Quebec Pesticides Management Code' (2014) 7 Golden Gate University Environmental Law Journal 5; L. Johnson, L. Sachs, and J. Sachs, 'Investor-State Dispute Settlement, Public Interest and U.S. Domestic Law' (2015) Columbia Centre on Sustainable Investment Policy Paper; G. Van Harten and D.N. Scott, 'Investment Treaties and Internal Vetting of Regulatory Proposals: A case study from Canada' (2017) 7 Journal of International Dispute Settlement 92; J. Kelsey, Regulatory Chill: Learnings from New Zealand's Plain Packaging Tobacco Law (2017) 17 Queensland University of Technology Law Review 21; K. Tienhaara, 'Regulatory Chill in a Warming World: The Threat to Climate Change Posed by Investor-State Dispute Settlement' (2018) 7 Transnational Environmental Law 229; E. Crosbie and G. Thomson, 'Regulatory Chill. Tobacco industry legal threats and the politics of standardised tobacco packaging in New Zealand' (2018) 131: 1473 New Zealand Medical Journal 25-41; M. Krajewski, 'Modalities for Investment Protection and Investor-State Dispute Settlement (ISDS) in TTIP from a Trade Union Perspective' (Friedrich Ebert Stiftung, Brussels, 2018) 7.

56 J. Ruggie, Report of the Special Representative to the Secretary General, Business and Human Rights: Towards Operationalizing the 'Protect, Respect and Remedy Framework', A/HRC/11/13 (2009), para. 30; UNCTAD, World Investment Report 2015 (UNCTAD 2015), 147; UNCTAD, World Investment Report 2018 UNCTAD 2018) 112; D. Gaukrodger, 'The Balance Between Investor-Protection and the Right to Regulate in Investment Treaties' (2017) OECD Working Papers on International Investment, 2017/02, 19-27.

57 X. Carim, Ambassador of South Africa to the WTO, 'International Investment Agreements and Africa's Structural Transformation: A Perspective from South Africa' (2015) 4 Investment Policy Brief, South Centre, Geneva, 2.

58 Productivity Commission, Bilateral and Regional Trade Agreements (Australian Government Productivity Commission 2010) 271-275; Productivity Commission, Trade and Assistance Review 2013-2014 (Australian Government Productivity Commission 2015) 86-87.

59 L. Wallach, “'Investor-State” Disputes in Trade Pacts Threaten Fundamental Principles of National Judicial Systems' (Public Citizen, Washington DC 2012); S. Anderson and M. Perez-Rocha, 'ISDS, Extractive Industries and the Case of Pacific Rim v EI Salvador,' in K. Singh and B. Ilge (eds) Rethinking Bilateral Trade Agreements. Critical Issues and Policy Choices (Madhyam, Both Ends, SOMO (2016) at 233-234.

${ }^{60}$ William Ralph Clayton, William Richard Clayton, Douglas Clayton, Daniel Clayton and Bilcon of Delaware Inc, v Canada, 14 May 2015, Dissenting Opinion of Professor Donald McRae, PCA Case No. 2009-04, 10 March 2015; L.E. Peterson, 'In NAFTA Dissent, Donald McRae Sees Chilling Effect - And “Remarkable Step Backwards in Environmental Protection" Due to Majority Ruling', Investment Arbitration Reporter, 21 March 2015; T. Landau in Australian Broadcasting Corporation, 'ISDS The Devil in the Trade Deal', Background Briefing, 26 July 2015 (cited in Gaukrodger (2017) 25 at fn 66).

61 S. Schill, 'Do Investment Treaties Chill Unilateral State Regulation to Mitigate Climate Change' (2007) 24 Journal of International Arbitration 469-477; J. Trakman and D. Musayelyan, 'Caveat Investors: Where do things stand now?' in C. L. Lim (ed), Alternative Visions of the Law on Foreign Investment (Cambridge University Press 2016) 69-100; Gaukrodger (2017) 21-27. 
- Institutional learning in government agencies arises from heightened awareness of the risks of an ISDS dispute and previous disputes involving that agency or the country.

- Power and influence among government agencies is increasingly realigned, with trade ministries playing a greater role in domestic policy decisions which were previously not their purview, such as policy advice on health, environment, indigenous rights, and natural resources. Advice may extend beyond technical legal risk assessment to include the fiscal costs of defending a dispute and a potential award, as well as extraneous foreign policy, reputational, and commercial concerns.

- Sponsoring ministries face a corresponding narrowing of the range of factors that would have been accorded priority when designing policy, due to the lack of guaranteed protection in investment agreements for the right to regulate consistent with the state's constitution, public interest, national security (in most agreements), or other international obligations relating to public goods, such as human rights, indigenous peoples, or climate change.

- Politicians and finance ministries may retreat from a policy position for fear of collateral damage when an investment dispute is threatened or lodged, such as investor strikes and flight, credit rating downgrades, or reputational harm.

- The above factors may become routinely incorporated in institutional decision-making through regulatory impact assessments, cost-benefit analyses, and 'better regulation' presumptions in favour of least burdensome options. Such regulatory management mechanisms are promoted by international agencies, such as the $\mathrm{OECD}^{62}$ and $A P E C^{63}$ and through regulatory coherence or cooperation chapters of free trade agreements. ${ }^{64}$ Those mechanisms are further reinforced by increased investor influence under the transparency provisions and 'best practice' consultation requirements of free trade agreements. ${ }^{65}$

(iv) Adjudicatory chill can be direct. For example, injunctive relief may compel a government to halt official investigations into alleged wrongdoing or litigation by private parties against an investor, thereby interfering with actions to hold investors to account. The impact can also be indirect, where approaches adopted by arbitral tribunals in other cases lead bodies that exercise judicial or quasi-judicial responsibilities to self-censor for fear of legal challenge. ${ }^{66}$

It is clear from the evidence that ISDS has contributed in significant ways to changes in government decision-making to the advantage of foreign investors - often maintaining the profit stream for activities that harm or pose risks to others - at the expense of other constituencies whose perspectives and interests are excluded or overridden.

\footnotetext{
62 See http://www.oecd.org/gov/regulatory-policy.

${ }^{63}$ See Nathan Associates, 'Final Report on Good Regulatory Practices in APEC Economies' (APEC and USAID 2017).

${ }^{64}$ See Trans-Pacific Partnership Agreement (signed 4 February 2016) [TPP], subsequently Comprehensive and Progressive Agreement for Trans-Pacific Partnership (entered into force 30 December 2018) [CPTPP], Chapter 25: Regulatory Coherence. ${ }^{65}$ See TPP and CPTPP, Chapter 26: Transparency and Anti-Corruption. See also J. Kelsey, 'The Trans-Pacific Partnership Agreement: A Gold-Plated Gift to the Global Tobacco Industry?'(2013) 39 American Journal of Law and Medicine 237.

${ }^{66}$ In his dissenting opinion in Clayton and Bilcon of Delaware Inc, $v$ Canada, Professor Donald McRae warned that the significant intrusion into domestic jurisdiction would create a chill on the operation of environmental review panels. Bilcon v. Canada (n 60) para. 48.
} 
This chilling effect is a consequence of serious flaws in the substantive and procedural rules of ISDS. In relation to costs alone, the prospect of an investor threatening or lodging a frivolous and vexatious dispute with an intent to chill is exacerbated by the advent of third-party funding. The costs of preparing a response, including operational and opportunity costs within government and tendering for and appointing counsel, are a further deterrent to policy makers. Where a country mounts a successful defence, costs are still not awarded in about one third of cases, ${ }^{67}$ and the sum awarded will not fully compensate for the country's fiscal outlay, opportunity costs, and costs from delays in implementing the measure. Moreover, investors who are ordered to pay costs may fail to do so; $; 8$ indeed a threat by the investor not to pay may pressure governments to negotiate down the actual amount awarded for the state's costs. The vagueness of investor protection rules and inconsistency of tribunal interpretations exacerbates the chilling effect by creating greater uncertainty and litigation risk for governments.

Many of these issues have been identified during the Working Group III process of consultation and in Phase 1. Yet they have not been appropriately or adequately discussed during Phase 2 . The agenda for the $37^{\text {th }}$ session in New York should include a discussion and assessment of whether and how the areas currently proposed for reform will address the fundamental problem of chill, and should develop a work plan that treats this as an independent issue.

\section{UNCITRAL's development obligations}

As part of the United Nations, UNCITRAL Working Group III needs to interpret and pursue its mandate in ways that reflect Member States' commitments to the Sustainable Development Goals (SDGs), including respect for human rights and governance structures that ensure inclusive participatory processes and equal access to justice. ${ }^{69}$

If the SDGs are to be achieved, international investment-and the legal frameworks that govern itwill need to play a supportive role. ${ }^{70}$ Indeed, Agenda 2030 specifically indicates that 'national development efforts need to be supported by an enabling international economic environment, including coherent and mutually supporting world trade, monetary and financial systems, and strengthened and enhanced global economic governance. ${ }^{71}$ Moreover, Agenda 2030 sets forth world leaders' 'commitment to pursuing policy coherence' in the international economic environment, and to 'respect[ing] each country's policy space and leadership to implement policies for poverty eradication and sustainable development. ${ }^{72}$ SDG 17 and targets 17.14 and 17.15 further embody these aims.

\footnotetext{
${ }^{67}$ M. Hodgson and A. Campbell, 'Damages and Costs in Investment Arbitration Revisited', Global Arbitration Review, 14 December 2017, p. 7

${ }^{68}$ UNCITRAL Working Group III (Investor-State Dispute Settlement Reform) 'Possible reform of investor-State dispute settlement (ISDS): Cost and duration. Note by the Secretariat' (31 August 2018) A/CN.9/WG.III/WP.153, para. 33.

69 There are, of course, many other UN obligations or commitments that provide context for this review, such as the UN Declaration on the Rights of Indigenous Peoples (UNDRIP) and the recently adopted UN Declaration on the Rights of Peasants (UNDROP).

70 See UNGA Res. 70/1 (21 October 2015) A/RES/70/1 United Nations (recording adoption of Transforming Our World: The 2030 Agenda for Sustainable Development (2015)), paras. 21, 27-28, 63, 67, targets 2.a, 7.a, 10.b, 17.5, 17.14, 17.15; see also L. Johnson, 'Space for Local Content and Strategies: A crucial time to revisit an old debate' (GiZ 2016); UN Committee for Development Policy, 'Policy Note: Expanding Productive Capacity: Lessons learned from graduating least developed countries' (UN Department of Economic and Social Affairs 2017) (discussing the contributions FDI can make to the SDGs).

${ }^{71}$ Transforming Our World: The 2030 Agenda for Sustainable Development (n 69), para. 63.

72 Ibid.
} 
A 2018 report of the UN Secretary General specifically noted that reform of international investment agreements remains an important area for improving the sustainable development impact of the international financial system, as such treaties 'often result in unintended consequences, such as constraining regulatory space or countries becoming vulnerable to large financial penalties from arbitration panels set up to settle investor-state disputes. ${ }^{173}$ These specific references in Agenda 2030 and accompanying documents underscore the critical relevance of IIA and ISDS reform for achieving the SDGs.

Another fundamental question for the Working Group to consider is how reforms can help to redress the current inadequacy of international investment agreements to achieve their commonly stated goal to encourage sustainable new investment for development purposes in states that need it. Without reviewing the voluminous empirical evidence on the issue here, it is sufficient to note that the evidence discloses, at best, an ambiguous relationship between the agreements and new investment. ${ }^{74}$ For example, one meta-analysis of the evidence testing the correlation between BITs and attracting foreign direct investment, suggests that their effects are 'economically negligible' ${ }^{75}$ The apparent disconnect between BITs and the larger goal of development is underscored by UNCTAD's conclusion that an annual investment gap of $\$ 2.5$ trillion remains to be filled for developing countries to meet development goals set out in the 2030 Agenda for Sustainable Development. ${ }^{76}$ Based on the current mandate of UNCITRAL Working Group III, the reforms presently under discussion would not alleviate some of the most serious development-related failings of the ISDS regime. For the agreements to be made supportive of development, something more than merely procedural reforms is required.

A further oft-stated objective of investment agreements and ISDS, integral to achieving SDGs, is to improve the domestic rule of law. The notion of improving the domestic rule of law is replete with assumptions about both process and substance. Empirical analyses indicate that being a respondent in an investment dispute, threatened or actual, does not result in the internalization of new norms. Where there is some knowledge of an investment dispute, there is no felt need to revise laws or practices; instead, learning remains confined to small groups of officials. ${ }^{77}$ ISDS claims may also have a negative impact on good governance and the rule of law. ${ }^{78}$ One of the primary means for strengthening domestic rule of law is to preserve the role of domestic legislative, judicial, and administrative processes in creating, interpreting, applying, and enforcing legal commitments. ${ }^{79}$ The

\footnotetext{
73 UNGA 'Report of the Secretary-General on the International Financial System and Development 72/203' (31 July 2018) UN Doc A/73/280, para. 62. See also ibid para. 73.

74 J. Bonnitcha, L.N. Skovgaard Poulsen, and M. Waibel, The Political Economy of the Investment Treaty Regime (Oxford University Press 2017) 159. See also J. Pohl, 'Societal Benefits and Costs of International Investment Agreements: A critical review of aspects and available empirical evidence' (2018) OECD Working Papers on International Investment, 2018/1.

75 C. Bellak, 'Economic Impact of Investment Agreements' (2015) Vienna Univ. of Econs. and Bus. Working Paper No. 200, at 19, available at https://epub.wu.ac.at/4625/1/wp200.pdf.

76 UNCTAD Press Release, 'Developing Countries Face \$2.5 Trillion Annual Investment Gap in Key Sustainable Development Sectors,' UNCTAD Report Estimates, UN Press Release, June $24 \quad 2014$, http://unctad.org/en/pages/PressRelease.aspx?OriginalVersionID=194.

77 M. Sattorova, The Impact of Investment Treaty Law on Host States: Enabling Good Governance? (Hart Publishing 2018$) 75$.

78 See, e.g., M. Sattorova, The Impact of Investment Treaty Law on Host States: Enabling Good Governance?(Hart Publishing 2018); T. Ginsburg, 'International Substitutes for Domestic Institutions: Bilateral Investment Treaties and Governance' (2005) 25 International Review of Law and Economics 107; L. Johnson, L. Sachs \& J. Sachs, 'Investor-State Dispute Settlement, Public Interest and U.S. Domestic Law' (2015) CCSI Policy Paper.

79 See e.g., V. Fikfak, 'Judicial Strategies and their Impact on the Development of the International Rule of Law' (2014) University of Cambridge Legal Studies Research Paper Series Paper No. 25; A. Nollkaemper, National Courts and the International Rule of Law (Oxford University Press 2011).
} 
focus should therefore be to strengthen these institutions. The empirical evidence also reveals that more is required to internalize good practices; namely, capacity-building initiatives rather than externally-imposed penalties. ${ }^{80}$ An investment court model, much like ISDS, would generate a substitute system for the settlement of investment disputes that risks disincentivizing and undermining this type of reform at the domestic level, especially in the absence of a duty to exhaust local remedies and deference to the domestic jurisdiction.

\section{Conclusion}

In interpreting the UNCITRAL mandate, Working Group III needs to keep in mind the original impetus for the current reform push, which lies in deep-seated concerns about the democratic accountability and legitimacy of the international investment regime as a whole, and especially of ISDS. As recognised in the early stage of the process, procedural reforms are necessary but not sufficient to address these concerns. The UNCITRAL reform process cannot solve all contentious issues, but if it is to alleviate the accountability and legitimacy crisis to a significant degree, its work plan should include steps to assess whether the issues identified for discussion and potential reform will genuinely address the core concerns. As we have argued in this paper, these issues should include the right to participation by affected parties, the customary duty to exhaust local remedies, the chilling effect of ISDS, and the relationship of the international investment regime to objectives of sustainable development and the rule of law.

80 Sattorova (2018) at 109-11. 